\title{
Creating inclusive environments and catering for individual needs
}

Thecla Kudakwashe Moffat, Binky Laureta and Lata Rana

\begin{abstract}
In early childhood education [ECE] settings, teachers need to be conscious of the diverse learning needs of individual children in their care. Meeting individual needs has roots in the rights discourse which aims to promote human rights, social justice and inclusion, removing barriers that may hinder learning for children with diverse needs (Gordon-Burns, Purdue, Rarere-Briggs, Stark \& Turnock, 2012; Mortimore, 2011). As the population becomes more diverse, ECE teachers are challenged more and more in their daily practice. In response to the increasingly diverse needs of young children, teachers are continually trying to incorporate inclusive practice (Macartney, 2012; Moffat, 2011). However, for various reasons, some ECE settings may find this difficult and this may be due in part to society's negative attitude towards difference (Macartney, 2012). Perhaps the biggest challenge teachers face today is dealing with issues of inequities (Christman, 2010). We propose that education be more focused on promoting an understanding of diversity and difference where educators understand each individual learner. In promoting social justice, strong advocacy is called for to meet individual needs in early childhood settings. Through a framework of inclusive education, this article discusses some existing challenges and presents ideas on how early childhood teachers could promote equity and social justice in their settings.
\end{abstract}

\section{Keywords:}

early childhood, equity, inclusive education, social justice

\section{Research Paper}

\section{INTRODUCTION}

Early childhood teachers have many responsibilities and challenges. They want to teach, to protect young children's rights and make efforts to meet each child's individual needs. Protecting children's rights is a challenge but it is a necessity because at this age children are defenceless to social influences (Christman, 2010). It is important for early childhood teachers to engage in self-review and reflection and in particular, to appraise their practice, taking a critical look to see if their early childhood education [ECE] settings are meeting individual needs of children and their families. As pointed out by UNESCO (1997), the early years are important for child development. It is a time when children discover diversity and difference in a positive way, especially if they have teachers who advocate for them. In light of this, it is very important to put measures in place to ensure that these attributes of respecting diversity and difference are fostered in early childhood settings.

Inclusive early childhood settings are those settings that recognise that all children and their families have rights to access quality education and care from settings of their choice regardless of their gender, culture, ability, disability or any difference (Education Review Office, 2012). In inclusive settings, teachers promote equity and social justice, and strive to give children and their families a sense of belonging while the individual needs of children are met (Moffat, 2011). To achieve this, teachers must be aware of dominant assumptions, beliefs, attitudes and exclusionary practices so that they can challenge these when advocating for children's rights. Stark, Gordon-Burns, Purdue, Rarere-Briggs and Turnock (2011) argue that everyday beliefs, attitudes and actions that are exclusive need to be challenged early in the education of children. This is because they have negative consequences for the inclusion of children with diverse needs and their families. Deficit beliefs and assumptions are the biggest barrier to inclusion (Macartney, 2012), therefore it is important for teachers to be conscious of these so that they protect the right of every child to quality early childhood education because inclusive early childhood education "is about rights, social justice and equity" (Gordon-Burns, Purdue, Rarere-Briggs, Stark \& Turnock, 2012, p. 155). A respect for every child's right contributes greatly to inclusive settings.

\section{WHY ARE INCLUSIVE ECE SETTINGS SO IMPORTANT?}

There is national and international legislation that supports human rights. The United Nations Convention on the Rights of the Child (1989) promotes the rights 
of children worldwide. In New Zealand, the Education Act (1989) makes it unlawful to discriminate against any child attending their local school regardless of abilities, disabilities, culture, race, ethnicity or language. The Human Rights Act (1993) states that people from birth to adulthood should be respected regardless of who they are. The Special Education Policy 2000 [SE2000] was introduced in 1996 with the intention of ensuring that children's individual needs are met without segregation. It was a landmark policy with the aim of supporting inclusion of students with special needs in educational settings and ensuring that their individual needs were met. In SE2OOO it is stated that, "the government's aim is to achieve, over the next decade, a world class inclusive education system that provides learning opportunities for all children" (Ministry of Education, 1996a, p. 5). This is the system that every child with diverse needs and their family wish for. However, two decades on, New Zealand is yet to claim that it has a world class inclusive education system. A lot of work still needs to be done. It requires dedication and advocacy from all New Zealanders who believe in social justice for a world class inclusive society to be achieved.

In ECE, this was further strengthened by the early childhood education curriculum, Te Whāriki (Ministry of Education, 1996b), which was

"... designed to be inclusive and appropriate for all children and anticipates that special needs will be met ... [and] programmes of each centre will incorporate strategies to fully include children with special needs" (Ministry of Education, 1996b, p. 11).

Te Whariki also states that all children, regardless of ethnicity, race, gender, age, background or ability should be given equal opportunities for learning. Though it does not prescribe the method to promote cultural diversity, it clearly states that education and care providers are expected to promote it. This was strengthened by the Education Early Childhood Services Regulations (SR 2008/204) which states that the curriculum should encourage, "children to be confident in their own culture and develop an understanding and respect for other cultures" (Article, 43, [i] [a] [iv]). These regulations recognise that families have aspirations for their children and it is the educators' responsibility to ensure that these are met in collaboration with families to ensure that children are not discriminated against.

\section{VALUES AND POLICIES}

Socially-just and inclusive education in enabling environments is what most families wish for. This is where ECE leaders, owners, managers and teachers have a huge role to play. Families have often been frustrated because the settings are not ready or may not know how to include a child with diverse needs. For example, Macartney and Morton (2009) narrate a story of a child with special education needs. Teachers felt it was the responsibility of the Education Support Worker [ESW] to educate and care for the child, and therefore this child was only allowed to attend the centre on the days and times when the ESW was there. In this case, the teachers did not consider the right of the child to be educated by qualified teachers and to be in the setting of the family's choice. In some cases of exclusion, those in settings argue that they are not ready for inclusive practice because the physical space is not accessible for every child. This was one reason given by a centre turning down a boy with cerebral palsy in a story which made headlines in July 2015 (Johnston, 2015). Denying children access was also cited in Purdue (2006) where she asserted that some settings simply did not accept disabled children or would put conditions on them such as coming with an adult each day. However, Watson and McCathren (2009) argued that designing settings to ensure that all children can be as actively involved and independent as possible is important. Consequently, educational leaders need to ensure that all areas of education and play are accessible. Creating inclusive environments is about changing our environment and practice to suit the needs of all children.

Once a physical structure suited to the needs of all children is in place, the next step is to look at centre policies and philosophy. Settings that clearly state their inclusive values and practise these are successful in inclusive practice (Moffat, 2011). Unfortunately however, values have been communicated within a range of excluding discourses, and in particular, the medical, charity, lay and rights discourses (Fulcher, 1989). The medical discourse emphasises diagnosis and specialised segregated facilities for children (Mortimore, 2011). The charity discourse views children as helpless and needing help. Whilst the lay discourse is associated with negative myths and stereotypes about these children (Neilson, 2005), the rights discourse is more concerned about social justice, human rights and inclusion (Mortimore, 2011). Gordon-Burns et al. (2012) advocate for teachers and educational leaders to consider children's rights when creating policies. Familiarity with legislation is key. Clarifying philosophy and policies in a sociallyjust language is important in creating enabling environments as the language used may determine whether a setting is inclusive or not. It is important that educational leaders and teachers be guided by the rights discourse and recognise the importance of social justice. A centre with an inclusive philosophy and policies will determine how each individual child is viewed and whether efforts will be made to meet 
individual needs (Moffat, 2011). We are therefore calling for educational leaders to stand up for children's rights to create enabling environments.

\section{THE ROLE OF THE TEACHER}

There is no doubt that even with environment philosophies and policies that are inclusive to all children, settings will not be inclusive without effective teachers. Their dedication plays a big part in meeting individual needs (Foreman, 2011). However, some teachers may have negative attitudes towards children with diverse needs (Macartney \& Morton, 2009; Neilson, 2005) and make it difficult to meet individual needs. Generally, New Zealand early childhood settings have a long history of children with diverse needs attending the same setting alongside their peers, but, as Macartney (2012) noted, attending the same setting as their peers does not necessarily mean their individual needs are met. It is important for teachers to see beyond the physical presence of children with diverse needs. In inclusive settings teachers are planning for individual children (Moffat, 2011). It is important for teachers to know that they do not need to change the child with diverse needs but that they need to change the programme and their ways of doing things to suit the needs of individual children (Ministry of Education, 2009). A willingness to engage positively with all children and their families, and create pedagogical practices that are reflective of an inclusive programme, is important. This is supported in the Education Early Childhood Services Regulations (SR 2008/204) which states that curriculum should,

"Respect and acknowledges the aspirations of parents, family, and whānau ... of the enrolled children in relation to the learning and development and decision making about those children" (Article 43, a, iv \& b).

For teachers to know the child and to provide for the child's needs they need to work in positive and effective collaboration with families. Researchers have noted that when parents and teachers collaborate effectively around children's learning, inclusion is enhanced (Dunn, 2008; Moffat, 2011). We are therefore encouraging teachers to actively engage with children and their families in order to give every child the best start in life regardless of their gender, ethnicity, abilities, disabilities or culture, and to find out what each child's needs are and respond to these. If it is something teachers are not familiar with it is important to seek help from those with more knowledge in the area, keeping in mind that while the child is enrolled in the centre, they are the responsibility of the teachers. For example, a child who is deaf or hard-of-hearing may need the centre to critically look at their noise levels and how the child is spoken to. Some children may need ECE settings to implement sign language to be fair and just, and to address these children's right to effective communication.

\section{LOOKING AT INCLUSIVE ECE THROUGH THE LENS OF CULTURAL DIVERSITY}

A major outcome of globalisation is increased migration of people to Western industrialised societies exposing all families to a multicultural life (Rana, 2012). Cultural diversity is an important issue in education where migrant families bring diverse languages and culture to the settings (Chan, 2006). This helps children, families and teachers to learn about different cultures and accept differences in a positive way. In order to provide an inclusive environment especially for children who are from different cultures, the curriculum needs to recognise differences and diversity and address cultural inequality so that all children can participate (Ang, 2010; Chan, 2006).

Provision of equal opportunity is embedded in $\mathrm{Te}$ Whāriki (Ministry of Education, 1996B). It recognises the diversity of ECE in the context of different cultural perspectives for children to "develop knowledge and an understanding of the cultural heritages" (Ministry of Education, 1996a, p. 9). However, there is the question of how to provide equal opportunities to diverse communities. It is argued in the literature that ECE settings only represent the values of the dominant social groups (Chan, 2011). Chan argues that the current discourse of multiculturalism practiced by early childhood teachers works only to marginalise diversity and encourages cultural homogeneity (Ang, 2010; Chan, 2011). Chan discusses that some educators believe all children go through the same developmental stages, have similar needs and reach their potential if these needs are met. However, this mono-cultural view fits only with dominant cultural perspectives and does not recognise cultural diversity, thus continuing to marginalise minority groups (Chan, 2006).

One characteristic of globalisation is the homogenising of cultural representation of western culture. In the context of ECE, as Pearson and Degotardi (2009) pointed out, the World Bank and UNESCO are encouraging globalisation influenced by the Western ideology of child development. There is research that suggests Western ideologies cannot be applied to all contexts (Kennedy, 2006; Pearson \& Degotardi, 2009; Sanagavarapu, 2010). In many Asian cultures, children's development is greatly influenced by others in the community and children's identity is construed in relationship and interaction with others (Kennedy, 2006; Pearson \& Degotardi, 2009). Also, behaviour and development are culture-specific, where, for example, in a cross-cultural study done by Shieffelin 
and Ochs (cited in Fleer, 2006), among Kaluli families in Papua New Guinea, the caregivers refrain from making eye contact with babies. They face infants towards the social group so that they interact with the social group early in life. Thus, different cultures have different practices and expectations of child development.

When respecting diverse cultures, it is about recognizing that cultures are not all the same, or homogenous, but heterogeneous. Different cultures and communities need to be recognised as diverse and respected for their differences. It is important that teachers do not force children into the dominant culture at the expense of their own culture. It also helps to challenge power relations to see the world critically and reflectively (Chan, 2011). We are proposing that teachers, children and families be supported and encouraged to share information about their culture and to help others avoid making assumptions about specific cultural groups (May \& Sleeter, 2010). Respect, positive relationships, positive attitude and role-modelling play a vital role. When teachers have positive attitudes about every child, when they role-model and include everyone despite their skin colour or cultural background, then children start to build friendships with others who respect and include them (Ponciano \& Shabazian, 2012).

\section{RECOMMENDATIONS AND CONCLUSIONS}

Early childhood teachers have many responsibilities and challenges in providing inclusive environments and catering for individual needs. It is important that teachers understand each child's needs including learning, physical, social, intellectual or cultural needs. Accepting diversity and difference in a positive way is an obligation. It is paramount to protect children's rights to uphold equity and social justice. There are national and international legislation that support human rights such as UNCROC, Education (Early Childhood Services) Regulations 2008 and Te Whāriki, and these guide teachers and ECE settings to be aware of children's rights and meet individual needs of children and their families. Social justice and inclusive education in enabling environments is what most families wish for. Therefore, settings where all children are actively involved and independent as possible, and centre policies and philosophy that clearly state inclusive values and where teachers are effective in advocating for children's rights, should be encouraged so that children receive the best start in life. It is imperative that early childhood teachers identify children who need focused attention for various reasons. Young children are the future, therefore it is important that teachers work in partnership with their families to understand them and help them grow up to be confident, competent and independent members of society.

\section{REFERENCES}

Ang, L. (2010). Critical perspectives on cultural diversity in early childhood: Building an inclusive curriculum and provision. Early Years: An International Journal of Research and Development. $30(1), 41-52$.

Chan, A. (2006). The teachers said my child is different. The First Years/NgāTau Tuatahi. New Zealand Journal of Infant and Toddler Education, 8(1), 34-38.

Chan, A. (2011). Critical multiculturalism: Supporting early childhood teachers to work with diverse immigrant families. International Research in Early Childhood Education, 2(1), 63-75.

Christman, D. E. (2010).Creating social justice in early childhood education: A case study in equity and context. Journal of Research on Leadership Education, 5(3.4) p.107-129.

Dunn, L. (2008). Perceptions of inclusive early intervention: Parents, early childhood teachers, speech-language therapists, early intervention teachers, and education support workers describe their understandings and experience of their shared task. New Zealand Research in Early Childhood Education Journal 11, 19-31.

Education Act 1989. Retrieved from: http://www.legislation.govt.nz/act/ public/1989/0080/latest/DLM175959.html

Education (Early Childhood Services) Regulations 2008 (SR 2008/204). Retrieved from: http://www.legislation.govt.nz/regulation/ public/2008/0204/latest/DLM1412501.html

Education Review Office (2012). Inclusion of children with special needs in early childhood services (December 2012). New Zealand Government, Wellington: New Zealand.

Fleer, M. (2006). The cultural construction of child development: Creating institutional and cultural intersubjectivity. International Journal of Early Years Education, 14(2), 37-47

Foreman, P. (2011). Inclusion in action (3rd Edition). Melbourne, Vic.: Cengage Learning Australia.

Fulcher, G. (1989). Disabling policies? A comparative approach to education policy and disability. London: Falmer Press.

Gordon-Burns, D., Purdue, K., Rarere-Briggs, B., Stark, R., \& Turnock, K. (2012). Key factors in creating inclusive early childhood settings for children with disabilities and their families. In D. GordonBurns, A. C. Gunn, K. Purdue \& N. Surtees, Te 
aoturoa tataki: Inclusive early childhood education: Perspective on inclusion, social justice and equity from Aotearoa New Zealand (pp. 155-173). Wellington, New Zealand: NZCER Press.

Human Right Act 1993. Retrieved from: http://www.legislation.govt.nz/act/ public/1993/0082/latest/DLM304212.html

Johnston, K. (2015). Special education: Boy turned down ... 3 times. New Zealand Herald. Retrieved from: http://www.nzherald.co.nz/nz/news/article.cfm?c_ $\mathrm{id}=1$ \&objectid $=11477175$

Kennedy, A. (2006). Globalisation, global English: 'Futures trading' in early childhood education. Early Years: Journal of International Research \& Development, 26(3), 295-306.

Macartney, B. (2012). Protecting the rights of disabled learners and their families to quality, inclusive early childhood education. Children's Magazine (Winter, p.63-66).

Macartney, B., \& Morton, M. (2009). Kinds of participation: Teacher and special education perceptions and practices of 'inclusion' in early childhood and primary setting. Paper presented at the Making Inclusive Education Happen, 28-30 September, Te Papa, Wellington, New Zealand.

May, S., \& Sleeter, C. E. (2010). Introduction. In S. May \& C.E. Sleeter, (Eds.), Critical multiculturalism: Theory and praxis (pp. 1-18). New York: Routledge.

Ministry of Education (1996a). Special Education 2000. Wellington: Learning Media.

Ministry of Education (1996b). Te Whāriki: He Whāriki Mātauranga mo ngā Mokopuna o Aotearoa: Early childhood curriculum. Wellington: Learning Media.

Ministry of Education (2009). Narrative assessment: $A$ guide for teachers. A resource to support the New Zealand curriculum exemplars for learners with special education needs. Wellington, New Zealand: Learning Media.

Moffat, T. K. (2011). Inclusion in early childhood settings in Aotearoa/New Zealand. Unpublished Masters Thesis, Massey University, Palmerston North, New Zealand.

Mortimore, T. (2011). Style difference in cognition, learning and management: Theory research and practice. In S Rayner \& E. Cools (Eds.), Putting styletheory into practice in the UK secondary schools: Inclusive schools for vulnerable learners (pp. 278-291). New York: Routledge.

Neilson, W. (2005). Disability: Attitudes, history and discourses. In D. Fraser, R. Moltzen \& K. Ryba
(Eds.), Learners with special needs in Aotearoa New Zealand (3rd ed.). (pp. 9-21). Nelson, New Zealand: Cengage Learning.

Pearson, E., \& Degotardi, S. (2009). Education for sustainable development in early childhood education: A global solution to local concerns? International Journal of Early Childhood, 41(1), 23-29.

Ponciano, L., \& Shabazian, A. (2012). Interculturalism: Addressing diversity in early childhood. Dimensions of Early Childhood. 40 (1), 23-30.

Purdue, K. (2006). Children with disabilities in early childhood education: "Special" or inclusive education? Early Childhood Folio, 10, 12-15.

Rana, L. (2012). Globalisation and its implications for early childhood education. He Kupu-the Word. 3(1), 14-22.

Sanagavarapu, P. (2010). What does cultural globalisation mean for parenting in immigrant families in the 21 st century? Australasian Journal of Early Childhood, 35(2), 36-42.

Special Education [SE 2000] Policy Guidelines (1996). Retrieved from: http://www.minedu.govt.nz/NZEducation/ EducationPolicies/SpecialEducation/ AboutUs/ContextOfOurWork/ SpecialEducationPolicyGuidelines/Introduction.aspx

Stark, R., Gordon-Burns, D., Purdue, K., Rarere-Briggs, B., \& Turnock, K. (2011). Other parents' perceptions of disability and inclusion in early childhood education: Implications for the teachers' role in creating inclusive communication. He Kupu, 20(1), 4-18.

United Nations Convention on the Rights of the Child 1989. Retrieved from: http://www.ohchr.org/Documents/ Professionallnterest/crc.pdf

UNESCO (1997). First steps: Stories of inclusion in early childhood education. International Consultation on Early Childhood Education and Special Educational Needs Education, Division of basic education ED 97/WS/39. Retrieved from: http://unesdoc.unesco.org/5E5EC343-5B2B-4BF0A40E-033F36ED32FA/FinalDownload/Downloadld953BCD9ADED342FADAC086200EA8F0F0/ 5E5EC343-5B2B-4BF0-A40E-033F36ED32FA/ images/0011/001102/110238eo.pdf

Watson, A., \& McCathren, R. (2009, March). Including children with special needs. Are you and your early childhood program ready? Beyond the Journal. Young Children on the Web, 1-7. 


\section{AUTHOR PROFILES}

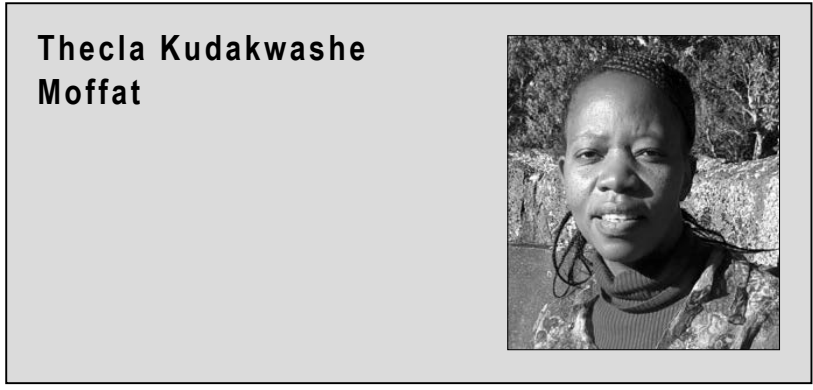

Thecla Moffat is a registered teacher who has been in the teaching field for over 20 years both overseas and in New Zealand. She started as a new entrant and Year 1 teacher for 10 years before transitioning to early childhood where she was an educator, a team leader and a mentor for student teachers. She then joined the tertiary sector in educating New Zealand's teachers for three years as a lecturer. Currently she is working in the Ministry of Education providing early intervention support for children with special needs and their families. She has a huge interest in inclusive education for children with diverse needs and promoting emotional and social competencies in the early years. She has done research in inclusive early childhood education and positive child guidance.

Email: thecla.moff@gmail.com or thecla.moffat@education.govt.nz

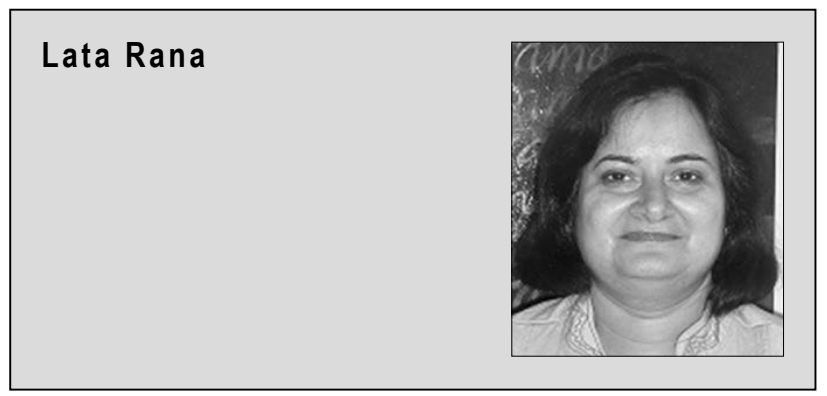

Lata Rana has a PhD in Education from the University of Melbourne. She has a wide experience of teaching and research. Lata has done extensive research on globalisation and women's access to education. Lata's research focus is on globalisation, cultural diversity and early childhood education research.

Email: drlata.rana@gmail.com or lata.rana@nztertiarycollege.ac.nz

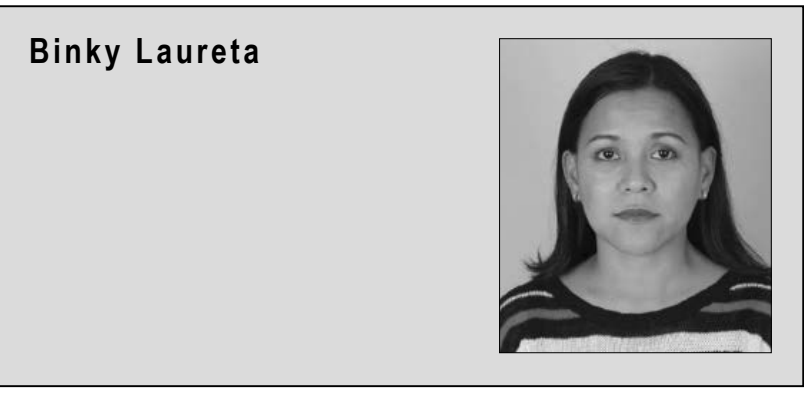

Binky Laureta has been involved in early childhood education for more than 15 years. She started her career as a preschool teacher, then lecturer in Manila, Philippines before moving to Auckland, New Zealand. She is currently lecturer and programme leader for the Graduate Diploma at New Zealand Tertiary College.

Email: binky42172@gmail.com or binky.laureta@nztertiarycollege.ac.nz 